\title{
Cochlear implant electrode array extrusion - is reimplantation feasible? - case report
}

\section{Ekstruzija elektrode umjetne pužnice - je li reimplantacija izvediva? - prikaz slučaja}

\author{
Marko Velepič ${ }^{1 *}$, Dubravko Manestar ${ }^{1}$, Petra Valković Zujić ${ }^{2}$, Goran Malvić ${ }^{1}$, \\ Sanja Zubović Velepič ${ }^{3}$
}

\begin{abstract}
Aim: To present two cases of late complications of cochlear implantation. Case report: In both cases extracochlear extrusion of the implant electrode occurred. More than ten years after successful cochlear implantation, the hearing performance gradually worsened to the point of no intelligibility in both patients. Otomicroscopy revealed chronic otitis media (COM) with an electrode in the external ear canal in implanted ears of both patients. Extracochlear electrode extrusion was noticed on CT scans in both cases. In the first case the device was explanted, the electrode was left in the cochlea and tympanoplasty was performed. Regardless the normal status of the middle ear, extracochlear extrusion occurred again. Conclusion: After extracochlear electrode extrusion, the reimplantation is likely to be unsuccessful.
\end{abstract}

Key words: chronic otitis media; cochlear implant; extracochlear electrode extrusion

\begin{abstract}
Sažetak. Cilj: Prikazati dva slučaja kasnih komplikacija kohlearne implantacije. Prikaz slučaja: U oba slučaja radilo se o ekstrakohlearnoj ekstruziji elektrode umjetne pužnice. Više od deset godina nakon implantacije $u$ oba pacijenta sluh je postepeno slabio do potpune nerazumljivosti. Otomikroskopijom je u oba pacijenta utvrđena kronična upala uha uz prisutnost elektrode u zvukovodu. Učinjena je kompjutorizirana tomografija koja je potvrdila ekstrakohlearnu ekstruziju elektrode. U prvom slučaju učinjena je eksplantacija umjetne pužnice, pri čemu je elektroda ostavljena u kohleji te timpanoplastika. Usprkos urednom cijeljenju uha, ekstruzija elektrode se ponovila. Zaključak: Nakon ekstrakohlearne ekstruzije elektrode velika je mogućnost da će reimplantacija biti neuspješna.
\end{abstract}

Ključne riječi: ekstrakohlearna ekstruzija elektrode; kronična upala uha; umjetna pužnica
${ }^{1}$ Clinic of Otorhinolaryngology Head and Neck Surgery, Clinical Medical Centre, University of Rijeka, Rijeka

${ }^{2}$ Clinic of Radiology, Clinical Medical Centre, University of Rijeka, Rijeka

${ }^{3}$ Department for Transfusion Medicine, Clinical Medical Centre, University of Rijeka, Rijeka

*Corresponding author:

Doc. dr. sc. Marko Velepič, MD, PhD Clinic of Otorhinolaryngology Head and Neck Surgery, Clinical Medical Centre, University of Rijeka Krešimirova 42, 51000 Rijeka e-mail: marko.velepic123@gmail.com

http://hrcak.srce.hr/medicina 


\section{INTRODUCTION}

Cochlear implantation is a widely accepted, safe procedure for patients with severe to profound hearing loss.

Major complications of the procedure which lead to revision surgery are rare. Overall long-term revision rate in cochlear implantation is $8.4 \%^{1}$. Main cause of revision surgery is device failure with more than half cases. Other possible causes include surgical error, skin flap troubles, patholo-

The history of cochlear implants starts in 1961 when the first implantation was performed. Since then, hundreds of thousands of such operations have been performed. Today, cochlear implantation is a widely accepted method of treating severe and profound hearing loss.

gy of the middle ear, vertigo, pathological processes in cochlea and finally allergy to silicone ${ }^{2}$. Most surgical complications are minor and can be treated medically or by minor surgical intervention $^{3-5}$.

Late complications which occur many years after the implantation are especially rare. Total number of delayed complications is less than $6 \%{ }^{6}$. Vestibular problems, device failures and taste problems are most common. Chronic otitis media with or without cholesteatoma, facial nerve palsy and electrode array extrusion occur less frequently ${ }^{7-9}$.

The aim of the presentation is to show two cases from the Clinic of Otorhinolaryngology Head and Neck Surgery, Clinical Medical Centre, University of Rijeka where, more than 10 years after the implantation, extracochlear electrode extrusion and chronic otitis media (COM) occurred simultaneously. Possible connection with synchronous development of the complications is discussed. The problem with the reimplantation and proposal of further treatment is also presented.

\section{CASE REPORT}

\section{First case}

A case of an 18-year-old patient, implanted in 2003 is reported. According to the data, the im- plantation was performed through posterior tympanotomy, without complications, and the electrode was inserted completely in the cochlea.

The patient was in regular postsurgical follow-up. Eleven years after the implantation, the patient had an episode of acute otitis media (AOM) that was successfully treated medically by primary care physician. Since that period, there has been a progressive loss in hearing performance, with no other symptoms. The device was fitted several times. Nevertheless, intelligibility in speech audiogram was gradually falling to a level without answer. Integrity test demonstrated failure of two electrodes, otherwise it functioned properly. The patient was referred to an ENT specialist and a polypoid mass of posterior ear canal wall was found.

Suspecting of cholesteatoma, a thin layer temporal bone CT was performed. It was discovered that the tip of the electrode was in the basal turn of the cochlea (Figure 1). Schüller X-ray confirmed this suspicion (Figure 2).

Given that this was a purulent ear with no response to antibiotic therapy, it was decided to perform a surgery in two stages. In the first procedure, cochlear explantation was planned. During the procedure, a posterior marginal defect of the eardrum was found as well as a defect of the posterior ear canal wall at the level of annulus. The rest of the canal wall was preserved.

Through the defect there was an ingrowth of the epithelium toward the mastoid cavity which formed a cholesteatoma pearl enveloping electrode proximal to marker ring. Distal to the marker ring the electrode was free from the diseased tissue. Half of the electrode was extruded out of the cochlea. It should be noted that the defect of the canal wall didn't seem to be iatrogenic. It seemed like a "mouse bite" $1.5 \mathrm{~mm}$ round defect around the electrode. As if bone resorption occurred due to electrode pressure. Cholesteatoma and the purulent, inflamed mucosa were removed.

Bibas et al. ${ }^{10}$ and Ray et al. ${ }^{11}$ suggest that the electrode should be left in place. Since the electrode distal to the marker ring seemed to be free from the disease, it was decided to try to reposition it to preserve the channel within the coch- 


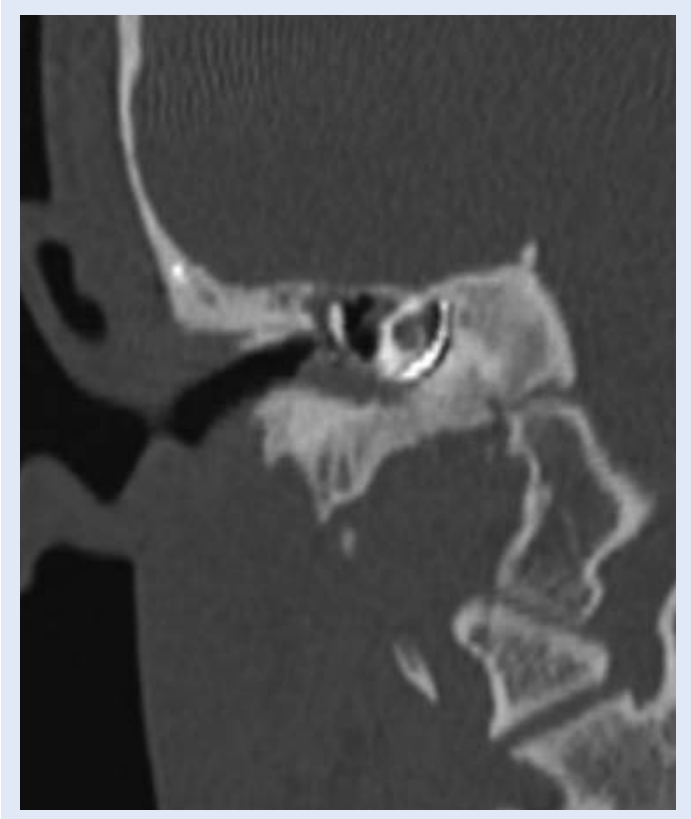

Figure 1. Computer tomography reveals cochlear electrode in the basal turn of the cochlea.

lea. It was fully repositioned in the cochlea up to the marker ring without any force. Then, it was cut at the level of cochleostomy and covered with some fibrous tissue to allow reimplantation. The device was explanted.

The defect of the eardrum and the posterior canal wall were reconstructed with chondroperichondrial graft of the cymba conchae. The patient was discharged without complications.

In the follow up, two months after the surgery, it was noted that the electrode had perforated between the chondroperichondrial graft and the bony canal wall and entered into the outer ear canal. Schüller X-ray confirmed that it was completely pushed out of the cochlea (Figure 3).

Due to extrusion of the electrode, it was decided to reimplant the opposite ear regardless modest audiological results were expected.

The patient was prepared for surgery. With the parents' consent, the exploration of the right ear with removal of the electrode and simultaneous implantation in the contralateral ear was done.

During surgery, it was found that the electrode was completely out of the cochlea and the cochleostomy site was clogged with fibrous tissue. The ear was dry and there was no sign of inflammation.

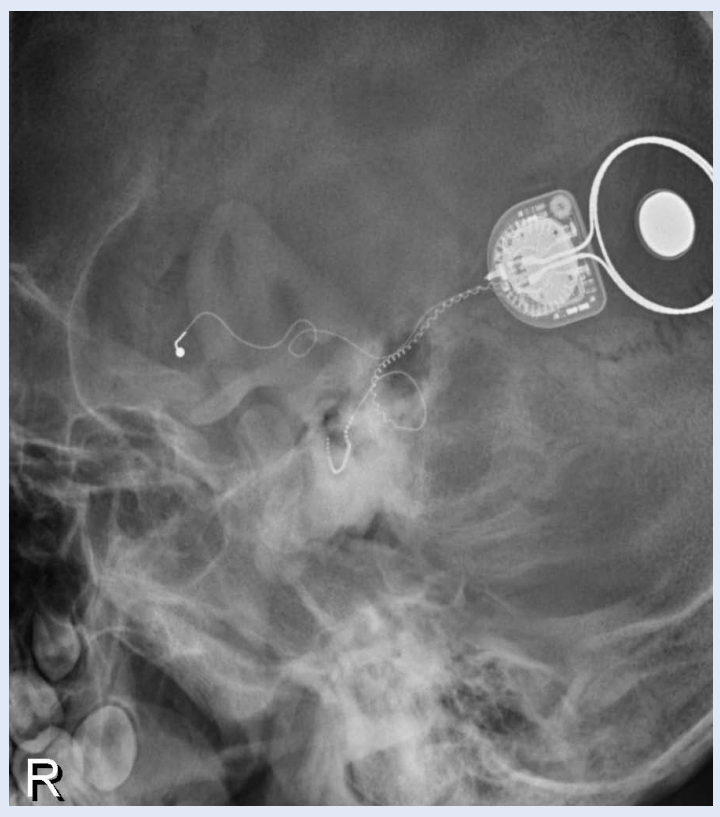

Figure 2. Schüller X-ray confirms the cochlear electrode position.

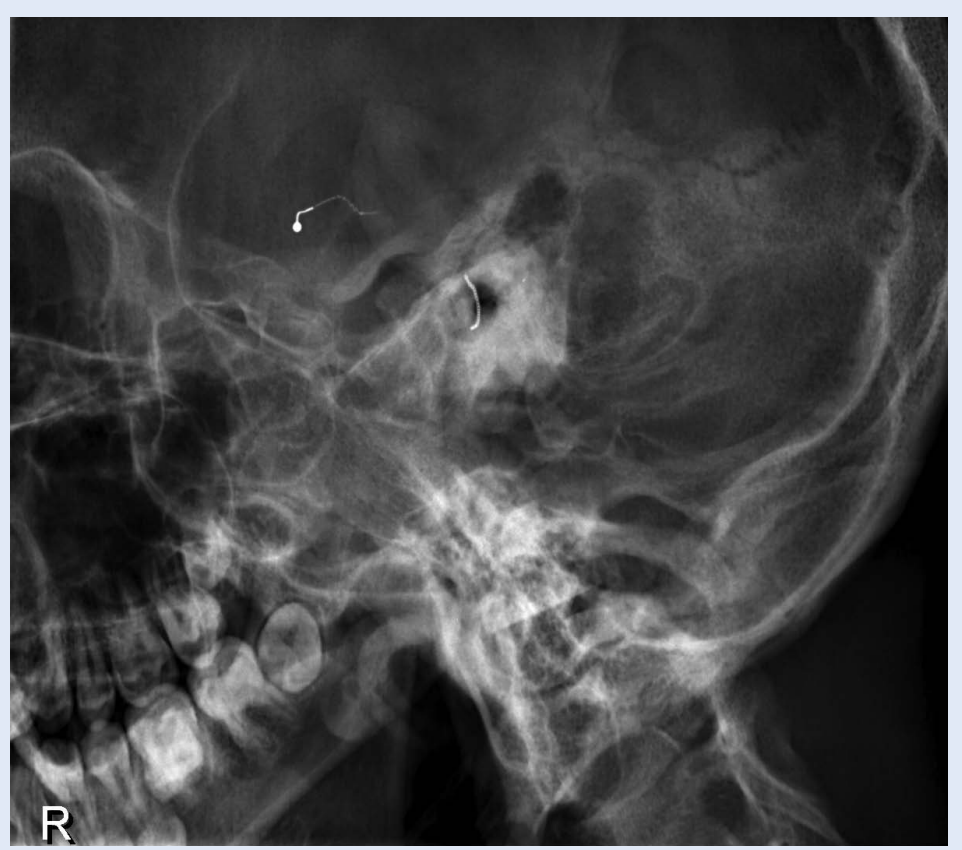

Figure 3. Schüller X-ray reveals cochlear electrode completely expelled outside the cochlea.

The electrode was removed and the eardrum was reconstructed. A typical cochlear implantation was done in the opposite ear through the posterior tympanotomy. The operation proceeded without complications, and after recovery, the patient was instructed to continue speech rehabilitation. 


\section{Second case}

The second case deals with a 35-year-old patient implanted in 1996. The implantation was also performed through posterior tympanotomy, without any complications and the electrode was inserted completely in the cochlea.

The patient performed well with no history of ear infection until 2011. Since 2011, 15 years after the implantation, the patient has had several episodes of ear discharge treated by primary care. Since then, the speech intelligibility has progressively dropped. Several processor fittings have been performed without success. In late 2013 the patient was referred to the Clinic due to an ear infection. A cochlear implant electrode was found in the ear canal. Purulent discharge was emerging through the eardrum defect (Figure 4). Radiological assessment was made and extrusion of the electrode was noted.

The exploration of the mastoid and the cavum tympani was performed. In the mastoid there was no sign of infection. Posterior ear canal wall was intact. In the cavum tympani a collection of purulent discharge was found around the electrode at the level of cochleostomy. Only $5 \mathrm{~mm}$ of the electrode was in the cochlea and the rest was extruded. No other pathology in the middle ear that could lead to extracochlear extrusion of the electrode was found.

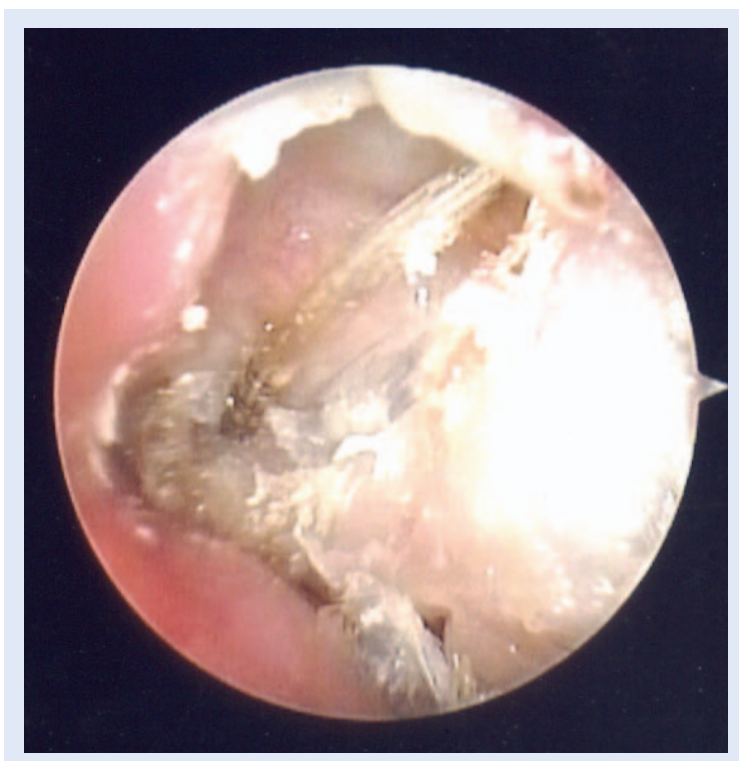

Figure 4. Intraoperative finding of the cochlear electrode extruded in the ear canal.
The device was explanted. The electrode was removed as well since the portion that was outside the cochlea was soaked with pus. The cochleostomy was covered with muscle in order to prevent spread of the infection. The eardrum defect was reconstructed with chondroperichondrial island graft of the cymba conchae. The postoperative period went well and the operated ear was dry, free of infection.

Regarding the previous case, it was decided to reimplant the opposite ear since there was high probability of extracochlear extrusion again. The implantation in the opposite ear through the posterior tympanotomy was made without any complications.

\section{DISCUSSION}

According to Vaid et al. extracochlear electrode extrusion is a potentially under-recognized complication of cochlear implantation. If electrode extrusion occurs, almost $60 \%$ of patients require revision surgery 9 . It depends on how many electrodes have extruded and whether the electrode protruded into the external auditory canal.

The potential of electrode migration was mostly assessed in young children due to skull growth, but revealed that there is no higher risk of electrode extrusion ${ }^{12}$.

Electrode extrusion could occur due to pathology within the cochlea or due to pathology within the middle ear ${ }^{13,14}$.

The cochlea is affected by the implantation. During the implantation inflammatory response is provoked by the insertion trauma ${ }^{15}$. Although the cochlear implant array consists of materials which are biocompatible, they are not inert. The electrode placed in the scala tympani is a foreign body which could cause inflammatory reactions, reactions towards foreign materials or even an allergic response, mostly to platinum electrodes ${ }^{2,13,16,17}$. The result of these reactions would constitute a potential danger of electrode extrusion.

Extrusion of the electrode leads to progressive loss of the hearing performance. Also, displacement of the electrode could cause a contact and pressure to the surrounding structures. If pressure is applied to the tympanal annulus or mar- 
ginal part of the posterosuperior eardrum, it could cause bone resorption by inducing osteoclasts at the pressure point ${ }^{18}$. Therefore, it could cause defect of the bony annulus and consequently marginal eardrum perforation.

In the literature there are no articles dealing with a significant number of implanted patients who experienced cochlear electrode extrusion second to acute or chronic otitis media. Acute otitis media in children occurs in "healthy" as well as in implanted ears ${ }^{19}$. After the implantation the incidence of acute otitis media lowers. It could be due to administration of vaccination which is almost mandatory nowadays, or is just a result of natural history of otitis media ${ }^{20-22}$. It has to be treated aggressively in the first months after the implantation.

The treatment is usually conservative, and surgical when needed. Due to regular check-ups by ENT specialists, ear infections do not usually take on a more comprehensive scale in implanted patients.

On the other hand, COM (with or without cholesteatoma) could be present before the implantation. With regard to present knowledge and surgical techniques, cochlear implantation is not contraindicated in such cases. Implantation is performed concomitantly with subtotal petrosectomy and EAC closure or as a two-stage procedure. It could also be done a certain period of time after a successful treatment if myringoplasty was performed ${ }^{23,24}$. If COM occurs after the implantation the inflamed tissue is removed and attempt should be made to save the implant. If it is not possible the electrode is cut at the level of cochleostomy and device is removed ${ }^{10}$.

It is important to mention that it is unknown which forces within the middle ear or the cochlea are necessary to remove the electrode. Also, there are no data available regarding in what period after the implantation we could expect the abovementioned cochlear reactions; e.g. could they occur more than 10 years after the implantation.

In two presented cases there has been a parallel occurrence of electrode extrusion and COM. The question arises whether the chronic inflammation within the middle ear provoked the extru- sion of the electrode from the cochlea, or the spontaneous extrusion of the electrodes mechanically provoked a chronic ear infection? What happened during the treatment of the first patient demands to take the second pattern into consideration. In the first procedure the device was explanted, the electrode was gently pushed till the marker ring, cut at the level of cochleostomy and then fixed with some fibrous tissue. The posterior canal wall and the eardrum were reconstructed and the ear was dry, free of inflammation. If the reason for the cochlear extrusion had been within the middle ear, the electrode would have stayed in the cochlea.

Surprisingly, the electrode was pulled out 2 months after the surgery, without any sign of ear infection. It is shown in the Figure 2 that the electrode was curved by the form of the cochlea. It was a proof that it was not bent while it was repositioned during the first surgery. Thus, there were (unexpected and unknown) forces within the cochlea that pulled the electrode out. There is a question of reimplantation in such cases. Should the implantation be delayed for a longer period of time, should the condition of the cochlea be followed by radiological methods or should the ear be reimplanted and electrode fixed in the mastoid cavity with a titanium clip $^{25}$.

For prudence of failure, it was decided to implant the opposite ear in both cases, although only modest functional results were expected ${ }^{26}$. Both patients have been followed for three years and no complications were observed.

\section{CONCLUSION}

Spontaneous extracochlear extrusion of the electrode occurs rarely. Its aetiology is unclear. When it occurs revision surgery and salvage of the implant is often unsuccessful. Also, the explantation will not solve the cause of the extrusion. If reimplantation in the same ear is planned a longer period of waiting with an electrode retained in the cochlea should be considered. If not, the reimplantation could lead to unnecessary surgery and expenses.

Conflicts of interest statement: the authors report no conflicts of interest. 


\section{REFERENCES}

1. Wang JT, Wang AY, Psarros C, Da Cruz M. Rates of revision and device failure in cochlear implant surgery: a 30year experience. Laryngoscope 2014;124:2393-9.

2. Kunda LD, Stidham KR, Inserra MM, Roland PS, Franklin D, Roberson JB, Jr. Silicone allergy: A new cause for cochlear implant extrusion and its management. Otol Neurotol 2006;27:1078-82.

3. Tarkan O, Tuncer U, Ozdemir S, Surmelioglu O, Cetik F, Kiroglu $M$ et al. Surgical and medical management for complications in 475 consecutive pediatric cochlear implantations. Int J Pediatr Otorhinolaryngol 2013;77: 473-9.

4. Bhatia K, Gibbin KP, Nikolopoulos TP, O'Donoghue GM. Surgical complications and their management in a series of 300 consecutive pediatric cochlear implantations. Otol Neurotol 2004;25:730-9.

5. Brito R, Monteiro TA, Leal AF, Tsuji RK, Pinna MH, Bento RF. Surgical complications in 550 consecutive cochlear implantation. Braz J Otorhinolaryngol 2012;78:80-5.

6. Terry B, Kelt RE, Jeyakumar A. Delayed Complications After Cochlear Implantation. JAMA otolaryngology-head \& neck surgery 2015;141:1012-7.

7. Rangabashyam M, Poh SS, Low WK. Electrode array extrusion through the posterior canal wall presenting as a delayed post-cochlear implant complication. Cochlear Implants Int 2015;16:341-4.

8. Dhillon VK, Hoa M, Winter M, Wilkinson EP. Extrusion of a cochlear implant positioner through the tympanic membrane in a pediatric patient: management of a delayed complication. Ann Otol Rhinol Laryngol 2014;123: 537-40.

9. Vaid N, Roland JT, Vaid S. Extracochlear electrode extrusion. Cochlear Implants Int 2011;12:177-80.

10. Bibas A, Phillips S, Bailey CM, Papsin BC. Chronic suppurative otitis media following paediatric cochlear implantation. Cochlear Implants Int 2006;7:167-78.

11. Ray J, Proops D, Donaldson I, Fielden C, Cooper H. Explantation and reimplantation of cochlear implants. Cochlear Implants Int 2004;5:160-7.

12. Roland JT, Jr., Fishman AJ, Waltzman SB, Alexiades G, Hoffman RA, Cohen NL. Stability of the cochlear implant array in children. Laryngoscope 1998;108:1119-23.

13. Nadol JB, Jr., O'Malley JT, Burgess BJ, Galler D. Cellular immunologic responses to cochlear implantation in the human. Hear Res 2014;318:11-7.

14. Neilan RE, Pawlowski K, Isaacson B, Roland PS. Cochlear implant device failure secondary to cholesterol granulo- ma-mediated cochlear erosion. Otol Neurotol 2012;33: 733-5.

15. Seyyedi M, Nadol JB, Jr. Intracochlear inflammatory response to cochlear implant electrodes in humans. Otol Neurotol 2014;35:1545-51.

16. Benatti A, Castiglione A, Trevisi P, Bovo R, Rosignoli M, Manara $R$ et al. Endocochlear inflammation in cochlear implant users: case report and literature review. Int J Pediatr Otorhinolaryngol 2013;77:885-93.

17. Lim HJ, Lee ES, Park HY, Park K, Choung YH. Foreign body reaction after cochlear implantation. Int J Pediatr Otorhinolaryngol 2011;75:1455-8.

18. Orisek BS, Chole RA. Pressures exerted by experimental cholesteatomas. Arch Otolaryngol Head Neck Surg 1987;113:386-91.

19. Liese JG, Silfverdal SA, Giaquinto C, Carmona A, Larcombe JH, Garcia-Sicilia J et al. Incidence and clinical presentation of acute otitis media in children aged $<6$ years in European medical practices--ERRATUM. Epidemiol Infect 2015;143:1566.

20. Luntz M, Khalaila J, Brodsky A, Shpak T. [Cochlear implantation in children with otitis media: third stage of a longterm prospective study]. Harefuah 2007;146:106-10, 66.

21. Migirov L, Yakirevitch A, Henkin Y, Kaplan-Neeman R, Kronenberg J. Acute otitis media and mastoiditis following cochlear implantation. Int J Pediatr Otorhinolaryngol 2006;70:899-903.

22. Rubin LG, Papsin B, Committee on Infectious $D$, Section on $\mathrm{O}-\mathrm{H}$, Neck S. Cochlear implants in children: surgical site infections and prevention and treatment of acute otitis media and meningitis. Pediat rics 2010;126:381-91.

23. Jang $\mathrm{JH}$, Park $\mathrm{MH}$, Song JJ, Lee $\mathrm{JH}$, Oh SH, Kim CS et al. Long-term outcome of cochlear implant in patients with chronic otitis media: one-stage surgery is equivalent to two-stage surgery. Journal of Korean medical science 2015;30:82-7.

24. Vincenti V, Pasanisi E, Bacciu A, Bacciu S. Long-term results of external auditory canal closure and mastoid obliteration in cochlear implantation after radical mastoidectomy: a clinical and radiological study. Eur Arch Otorhinolaryngol 2014;271:2127-30.

25. Muller J, Schon F, Helms J. [Reliable fixation of cochlear implant electrode mountings in children and adults-initial experiences with a new titanium clip]. Laryngorhinootologie 1998;77:238-40.

26. Jbarah R, Geal-Dor M, Rich S, Adler M, Yehezkely MK. Results of second cochlear implant with long inter-implant delay. Journal of basic and clinical physiology and pharmacology 2013;24:205-8. 